\title{
Obsidian use in the mosaic of the St. Juvenal church, Narni (Italy): chemical characterization and origin
}

Pasquale Avino ${ }^{1 *}$, Pietro Moioli ${ }^{2}$, Alberto Rosada ${ }^{3}$ and Claudio Seccaroni ${ }^{2}$

\begin{abstract}
Tesserae from the mosaic on the front of the San Giovenale chapel inside the Narni Cathedral were analyzed through non-destructive XRF analysis for the characterization of both colouring matters and opacifiers of the glass matrix. Subsequently, the concentration of the elements present at trace levels $\left(\mu \mathrm{g} \mathrm{g}^{-1}\right)$ was determined by means of Instrumental Neutron Activation Analysis (INAA) for comparisons with obsidians of known provenance and well-studied micro-elemental composition, in order to identify the geographical origin of the obsidian used in this Middle Ages mosaic. The main result is that the black tesserae were made with obsidian fragments coming from the Sardinia deposits (probably, Arci Mountain site C).
\end{abstract}

Keywords: Obsidian, Mosaic, Medieval glass, XRF, INAA

\section{Introduction}

On the façade of the Oratory of San Giovenale, which is located in the Cathedral of Narni (Central Italy), is a mosaic depicting the Majestas Christi (Christ in Majesty) (Figure 1), in which the figure of Christ is inserted into a circular mandorla flanked by saints. This Majestas is considered one of the oldest Medieval wall mosaics of Central Italy, with the exception of those of Rome. During the Middle Ages, in Central Italy, above all in Tuscany, wall mosaics were relatively numerous in the $13^{\text {th }}$ and $14^{\text {th }}$ centuries. On the contrary, we have no knowledge of previous wall mosaics dating from the $10^{\text {th }}$ and $11^{\text {th }}$ centuries. For these reasons, the mosaic of Narni Majestas is an early example of the revival of the mosaic and the new interest in it in the $12^{\text {th }}$ century whose use had long been neglected in great as in small art centres of Italy. In fact, the last wall mosaic prior to the $12^{\text {th }}$ century is located in Rome which dates back to the middle of the $9^{\text {th }}$ century.

The location of the Narni mosaic back slightly hidden and difficult to access, has undoubtedly contributed to

\footnotetext{
* Correspondence: p.avino@inail.it

'DIPIA, INAIL settore Ricerca, Certificazione e Verifica, via Urbana 167, 00184, Rome, Italy

Full list of author information is available at the end of the article
}

preserve the work in the interventions that changed the decoration of the interior walls of the cathedral.

The obsidian, natural glass from volcanic origin formed by rapid solidification from a liquid state $\left(\mathrm{SiO}_{2}\right.$ as main component ranging between $66 \%$ and $75 \%$ ) [1], has been widely employed for hand-manufactured goods both in the Middle East and the Mediterranean area since long time.

Obsidian is widely considered an ideal material for source tracing using elemental methods of analysis. The literature of the past two decades includes a number of papers which discuss the nature of production, trade and exchange, and review the history of their archaeological interpretation [2]. Trade is defined in the archaeological record as the movement of the materials themselves, not their ownership or possession.

In order for a provenance study to be successful, there are several prerequisites: 1) all relevant geological sources should be known; 2) these sources must be characterized for the physical properties or parameters; 3 ) one or more properties must be homogeneous within an individual source; 4) measurable, statistically valid differences between sources must exist for one or a combination of these parameters; and 5) they must be measurable using analytical methods appropriate $[2,3]$. 


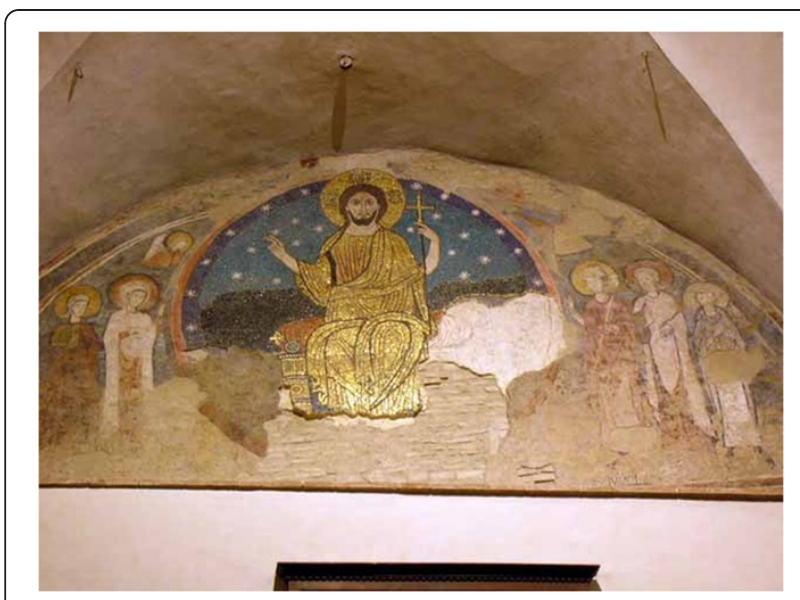

Figure 1 Mosaic depicting the Majestas Christi (Christ in Majesty) on the entrance of San Giovenale Chapel inside the Cathedral of Narni (Umbria, Italy).

The process of taking compositional data and attributing a provenance from a certain source is not a trivial task [4]. In order to determining the provenance origin, we used elaborations such as bivariate plots and source discrimination approach. For instance, in the obsidian study, bivariate plots of certain trace elements (e.g., La/Sc vs $\mathrm{Cs} / \mathrm{Sc}, \mathrm{Eu}$ vs $\mathrm{Cs}$ ) appear to be sufficient for visual assignment of artefacts to individual island sources, at least in the Mediterranean [4]. On the other hand, Neutron Activation Analysis introduces strong analytical advantages (described in Experimental section) but the presence of some possible interferences requires a special statistical treatment of the samples (i.e. source discrimination).

Provenance studies are important for the knowledge of trading routes but in some cases they are not so easy to find this out, especially considering the multiple Sardinian sources [4].

The recovery of some original tesserae allowed the identification of interesting materials. Among the different analytical methods successfully employed in archaeological provenance studies on many materials, the tesserae were examined initially using non-destructive analysis by X-Ray Fluorescence (XRF) and successively through Instrumental Neutron Activation Analysis (INAA).

\section{Results and Discussion}

\section{X-ray fluorescence analysis (XRF)}

Although it is impossible using portable XRF in order to detect an accurate chemical composition of glass, nevertheless this technique allows, in an absolutely nondestructive way, recognizing and semi-quantitatively evaluating the presence of the chemical elements [5-7] related to the colouring agents and to the opacifiers of the vitreous mass. Table 1 shows the results of XRF analysis. The tesserae were found to be of two types: the first type relates tesserae obtained through a coloured glass (samples 1-11 and 15-17), the second type of tesserae has been obtained from a glass having a natural origin (obsidian) and they have been used for the black (samples 12-14). Antimony compounds, containing tin impurities, have been found as opacifiers of the vitreous

Table 1 XRF results expressed as cps (tr: trace)

\begin{tabular}{|c|c|c|c|c|c|c|c|c|c|c|c|c|c|c|c|c|c|}
\hline$\#$ & Colour & $\mathrm{K}$ & $\mathrm{Ca}$ & $\mathrm{Mn}$ & $\mathrm{Fe}$ & Co & $\mathrm{Cu}$ & $\mathrm{Pb}$ & $\mathrm{Sr}$ & $Y$ & $\mathrm{Zr}$ & $\mathrm{Nb}$ & Sn & $\mathrm{Sb}$ & $\mathrm{Ba}$ & La & $\overline{\mathrm{Ce}}$ \\
\hline 1 & blue-green & & 8.2 & 11 & 40 & & 154 & 13 & & & & & 15 & 125 & 4.2 & & \\
\hline 2 & blue-green & & 8.7 & 10 & 36 & & 141 & 11 & 0.43 & & & & 17 & 137 & 4.9 & & \\
\hline 3 & blue-green & & 8.5 & 11 & 43 & & 161 & 13 & 0.57 & & & & 11 & 101 & 3.3 & & \\
\hline 4 & blue-green & & 6.7 & 9.2 & 34 & & 127 & 8.7 & 0.29 & & & & 15 & 122 & 4.4 & & \\
\hline 5 & blue-green & & 6.4 & 8.2 & 30 & & 121 & 11 & $\operatorname{tr}$ & & & & 13 & 111 & 3.9 & & \\
\hline 6 & light blue & & 12 & 11 & 35 & & 132 & 2.3 & 0.51 & & & & 16 & 165 & 4.7 & & \\
\hline 7 & light blue & & 6.5 & 15 & 40 & & 36 & 1.4 & $\operatorname{tr}$ & & & & 3.2 & 48 & 2.6 & & \\
\hline 8 & light blue & & 11 & 7.5 & 36 & & 194 & 4.2 & 0.48 & & & & 18 & 141 & 3.4 & & \\
\hline 9 & light blue & & 5.4 & 4.3 & 19 & & 106 & 1.9 & 0.39 & & & & 12 & 119 & 3.2 & & \\
\hline 10 & light blue & & 7.3 & 8.2 & 30 & & 161 & 3.3 & 0.47 & & & & 17 & 171 & 3.7 & & \\
\hline 11 & dark blue & & 10 & 21 & 49 & 5.4 & 18 & 5.0 & 0.41 & & & & 5.1 & 176 & 5.3 & & \\
\hline 12 & black & 2.9 & 2.1 & 2.8 & 134 & & & & & 0.19 & 1.0 & 0.29 & & & 29 & 0.90 & 4.3 \\
\hline 13 & black & 3.6 & 2.3 & & 147 & & & & & 0.15 & 1.1 & 0.34 & & & 22 & 0.70 & 3.0 \\
\hline 14 & black & 1.9 & 2.0 & & 86 & & & & & 0.22 & 0.81 & $\operatorname{tr}$ & & & 27 & 0.71 & 3.8 \\
\hline 15 & white & & 120 & 0.36 & 2.0 & & & & & & & & & & & & \\
\hline 16 & colourless & & 20 & 8.7 & 23 & & & & 0.53 & & & & $\operatorname{tr}$ & 53 & 4.0 & & \\
\hline 17 & colourless & & 14 & 11 & 27 & & & & 0.53 & & & & & 74 & 5.6 & & \\
\hline
\end{tabular}


mass. All the tesserae made of blue-green transparent glass (samples 1 to 5 ) and of a translucent blue glass (samples 6 to 10), without exception, have been coloured with copper compounds. The dark blue tessera (sample 11 ) is the only one to contain cobalt. Impurities usually associated with cobalt ( $\mathrm{As}, \mathrm{Ni}, \mathrm{Bi}, \mathrm{In}$ and $\mathrm{Zn}$ ) were not found. The slight increase in manganese amounts, compared to other samples of glass, may be due to cobalt ore used. It could be asbolite, a mineral consisting of manganese oxides with high capacity of cobalt (20-30\%).

As white tesserae (sample 15) a highly homogeneous and compact limestone has been used. XRF analysis detected the presence of impurities of iron and manganese, while strontium, which is generally associated with calcium is absent.

Colourless glass tesserae (samples 16 and 17) containing amounts of antimony can be in amount equal to half the amount found in other coloured tiles. It suggests that antimony compounds were used for decolouring the glass matrix, a well known technique for classic world, but not documented in Medieval glasses.

\section{Analysis of obsidian tesserae by Neutron Activation Analysis}

The composition of trace elements determined by neutron activation analysis of obsidian was compared to those of other obsidians from known sites (Table 2). In particular, the works of Hallam et al. [8] and Ammerman et al. [9] were taken into account. On the basis of trace elements determined, it is possible to affirm that the source of the obsidian used as black tesserae in the mosaic of San Giovenale comes from Sardinia.

To confirm this hypothesis the composition of the two samples was compared to obsidian samples of well-known geographical provenance to get information about the deposit areas and the route followed for shipping such material [10-14].

We analyzed and compared the samples with obsidian samples coming from the western Mediterranean area such as Sardinia (Arci Mountain, site A and C, SA and SC) and Sicily (Lipari). These areas can be considered as target for such materials. According to the information reported in literature $[4,8,10,12,15-17]$, it is also possible to individuate the deposit sites of each obsidian samples by comparing the ratios of some elements, e.g. La/Sc vs $\mathrm{Cs} / \mathrm{Sc}$. This plot is shown in Figure 2 describing that the samples used as standards make three well-separated groups (Sardinia A, SA, Sardinia C, SC, and Lipari). The two samples collected from the Narni Majestas, show a quite similar composition to those grouped in the SA and SC groups. Particularly, the ratios of the two samples are equidistant from the SA and SC groups.

Other useful information can be obtained by analyzing the correlation between $\mathrm{Eu}$ and $\mathrm{Cs}$ concentrations
(Figure 3) and using the complete discrimination among the sites, i.e. source discrimination. The source discrimination approach, introduced by Aspinall et al. [14], reduces uncertainties arising from variations in counting geometry (analytical characteristic of the INAA methodology) due to the widely varying shape and mass of samples. This achievement is still confirmed by the source discrimination vs. Fe/Sc plot (Figure 4). To calculate the source discrimination we used the following formula [14]:

$$
\frac{1}{[\mathrm{Sc}]}\left([\mathrm{Cs}]+[\mathrm{Ta}]+\frac{\mathrm{Rb}}{100}+\frac{[\mathrm{Th}]+[\mathrm{La}]+[\mathrm{Ce}]}{10}\right)
$$

Differently from other studies the elements Ce, Cs, La, $\mathrm{Rb}, \mathrm{Sc}$, Ta and Th, are sufficient to separate the obsidian samples from possible artefacts in different groups with high probability: in this case no artefacts are present neither in the samples neither in the obsidian standards (Figure 4). These two last elaborations allow to specify the provenience of the tesserae. In fact, even if in Figure 3 the three standard groups are quite different, the samples 12 and 14 are more closer to the Sardinia samples than to the Lipari ones. Again, the SC samples seems to show a composition more similar to our mosaic tesserae than to the SA samples.

For all the reasons evidenced in Figures 2, 3, 4 the obsidian analyzed in the tesserae of the Narni mosaic can be attributed to Sardinia deposits and, in particular, Arci Mountain site $\mathrm{C}$ can be considered the main deposit.

This is interesting from an historical point of view. In fact, the presence of obsidian in black tesserae could be explained by the difficulty of obtaining a black colour for the glasses. Moreover, there are indications that suggest the reuse of ancient colourless glass tesserae. Further, we showed the presence of antimony compounds for opaque or discoloured glass.

The peripheral position of Narni and the resumption of the mosaic technique, after a hiatus of nearly two centuries, may explain the use of unusual materials. The distance between Narni and sites of possible supply of obsidian, is actually much greater than that which separated at that time Narni from centres of glass production. Taking into account that Narni is located in the valley of the Tiber, the route would have been more plausible one that leads to Rome, a distance of only 90 $\mathrm{km}$. In this city, no doubt, black glass supply had certainly been easy. Moreover, the presence of obsidian was never found in Medieval mosaics in Rome. Every reason to believe that in the case of the mosaic of San Giovenale - at least in regard to the black tesserae (technically more difficult to obtain) - raw materials were reused collecting it from a nearby site. 
Table 2 Trace element composition (in ppm) of obsidian samples (SA: Sardinia site A; SC: Sardinia site C;) investigated and used for identifying the provenience of the two obsidian tesserae (samples 12 and 14)

\begin{tabular}{|c|c|c|c|c|c|c|c|c|c|c|c|c|c|c|c|c|c|c|c|c|c|c|c|}
\hline & 14 & 12 & SA & SA & SA & SA & SA & SA & SC & SC & SC & SC & SC & SC & Lipari & Lipari & Lipari & Lipari & Lipari & Lipari & Lipari & Lipari & Lipari \\
\hline Na \% & 3.04 & 3.11 & 2.64 & 2.91 & 2.29 & 2.33 & 2.42 & 2.775 & 2.26 & 2.66 & 1.94 & 2.10 & 2.46 & 2.37 & 2.84 & 3.19 & 2.39 & 2.29 & 2.68 & 1.87 & 2.51 & 2.96 & 3.41 \\
\hline Sc & 3.51 & 3.47 & 4.2 & 4.7 & 4.51 & 4.31 & 5.23 & 4.45 & 3.55 & 4.05 & 2.7 & 3.06 & 3.8 & 3.88 & 1.18 & 1.3 & 0.95 & 0.92 & 1.09 & 1.42 & 1.23 & 1.33 & 1.43 \\
\hline $\mathrm{Fe} \%$ & 1.97 & 2.01 & 0.87 & 1.07 & 0.95 & 0.88 & 1.08 & 0.97 & 1.29 & 1.46 & 0.92 & 0.99 & 1.375 & 1.27 & 1.37 & 1.57 & 0.86 & 0.84 & 1.16 & 0.92 & 1.36 & 1.445 & 1.53 \\
\hline Zn & 92.2 & 93.1 & & & 66.6 & 62 & 67.2 & & & & 46 & 49 & & 54 & & & 54.5 & 53.7 & & 58.4 & & & \\
\hline $\mathrm{Sb}$ & 0.47 & 0.55 & & & 0.05 & 0.17 & 0.19 & & & & 0.04 & & & 0.15 & & & 0.94 & 0.97 & & 1.11 & & & \\
\hline La & 34.4 & 34.7 & 22.2 & 24.5 & 22.9 & 21.1 & 20.9 & 23.35 & 60.4 & 66.8 & 56 & 56 & 63.6 & 62.2 & 57 & 66 & 49.7 & 53.6 & 56.6 & 50.6 & 55 & 64 & 73 \\
\hline $\mathrm{Ce}$ & 135 & 138 & 46 & 56 & 58.2 & 50.6 & 62.6 & 51 & 120 & 170 & 0.78 & 0.67 & 145 & 0.83 & 110 & 160 & 95.5 & 100.9 & 116.6 & 102.2 & 130 & 150 & 170 \\
\hline $\mathrm{Nd}$ & 45 & 51 & & & 18.7 & 17.3 & 14.8 & & & & 34.3 & 26.3 & & 16.1 & & & 16.7 & 22.4 & & 21.9 & & & \\
\hline Sm & 9.82 & 9.78 & 5.5 & 6.1 & 5.12 & 4.85 & 5.32 & 5.8 & 6.5 & 8 & 6.42 & 6.41 & 7.25 & 7.49 & 6.8 & 7.7 & 5.24 & 5.94 & 6.42 & 5.72 & 7.2 & 7.95 & 8.7 \\
\hline Eu & 1.69 & 1.66 & 0.2 & 0.6 & 0.35 & 0.32 & 0.35 & 0.4 & 1.2 & 1.4 & 0.86 & 0.81 & 1.3 & 1.02 & 0.1 & 0.2 & 0.08 & 0.09 & 0.118 & 0.09 & 0.1 & 0.15 & 0.2 \\
\hline $\mathrm{Tb}$ & 0.96 & 0.93 & & & & 0.63 & 0.72 & & & & & 0.57 & & 0.61 & & & 0.53 & 0.76 & & 0.67 & & & \\
\hline $\mathrm{Yb}$ & 10.9 & 10.6 & & & & 0.04 & 0.05 & & & & & 0.02 & & 0.03 & & & 0.05 & 0.05 & & 0.05 & & & \\
\hline $\mathrm{Rb}$ & 129.7 & 129.2 & & & 229 & 201 & 245 & & & & 95.4 & 120.5 & & 149.7 & & & 221 & 217 & & 228 & & & \\
\hline Cs & 1.64 & 1.60 & 3.7 & 4.6 & 4.25 & 3.72 & 4.67 & 4.15 & 2 & 2.8 & 1.42 & 1.7 & 2.4 & 2.02 & 16.5 & 20.2 & 15 & 15.7 & 16.8 & 15.4 & 17.7 & 18.85 & 20 \\
\hline $\mathrm{Ba}$ & 506 & 610 & & & 287 & 132 & 216 & & & & & 621 & & 823 & & & 1436 & 1285 & & 3813 & & & \\
\hline $\mathrm{Hf}$ & 16.5 & 16.1 & 3.1 & 4.1 & & 3.85 & 2.77 & 3.6 & 6 & 8.2 & & 6.26 & 7.1 & 8.11 & 5.9 & 9.3 & 6.84 & 7.18 & 7.30 & 7.13 & 5.7 & 7.55 & 9.4 \\
\hline U & 3.88 & 3.80 & 17 & 17 & 3.38 & 2.55 & 2.61 & 17 & 1 & 3.2 & 1.42 & 1.12 & 2.1 & 1.67 & 23 & 24 & 4.96 & 6.09 & 14.5 & 5.66 & 15 & 20 & 25 \\
\hline Th & 13.1 & 12.7 & 16 & 21 & & 12.3 & 15.2 & 18.5 & 30 & 39 & & 16.4 & 34.5 & 21.4 & 42 & 63 & 36.7 & 37.5 & 44.8 & 36.9 & 54 & 64 & 74 \\
\hline Ta & 8.13 & 8.26 & & & & 2.77 & 3.43 & & & & & 1.27 & & 1.63 & & & 1.46 & 1.5 & & 1.5 & & & \\
\hline
\end{tabular}




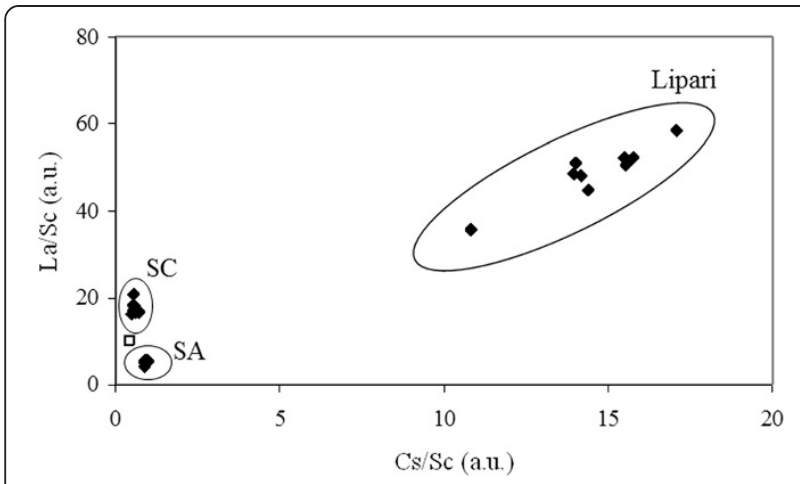

Figure 2 Attribution of the obsidian samples to the source groups by means of INAA on the basis of ratios of the contents of La and SC and CS and Sc.

It is also possible that recycled material were used also for some glass tesserae, namely for those made with colourless and blue glass. In fact, in these tesserae the low presence of $\mathrm{Mn}$ (respect to $\mathrm{Fe}$ ) and a noticeable presence of $\mathrm{Sb}$ seems to point out the use of $\mathrm{Sb}$ compounds to decolouring the glass matrix. Generally, this decolouring technique is associated to the very important and high quality glass products of the classical Antiquity, unknown in Occident after the fall of the Roman Empire: in fact, the use of $\mathrm{Sb}$ as decolouring has never been identified in Medieval European contests [18]. Similarly, the absence of marker elements associated to cobalt used for colouring glass from the $13^{\text {th }}$ century could point out the use of recycled blue glass or the persistence of the production of cobalt based blue coloured glass since the Antiquity; however, the fact that cobalt was used only for dark blue tesserae, while light blue tesserae were coloured with copper compounds seems to support the first hypothesis.

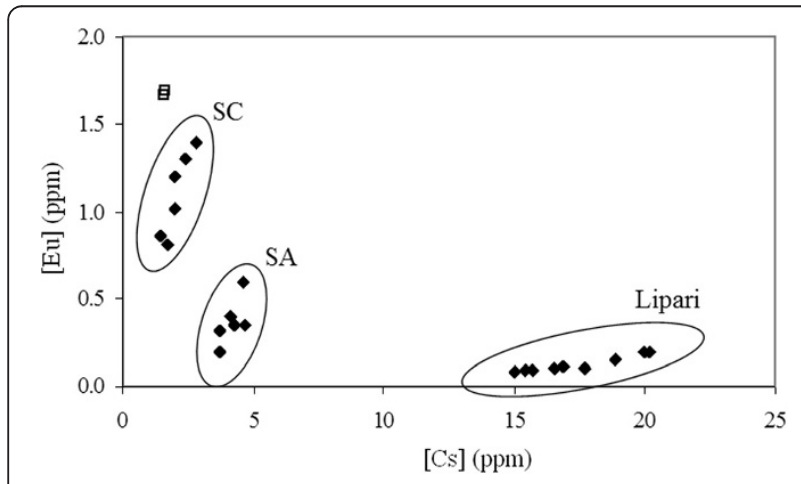

Figure 3 Attribution of the obsidian to the source groups by means of INAA on the basis of the contents of Eu and Cs.

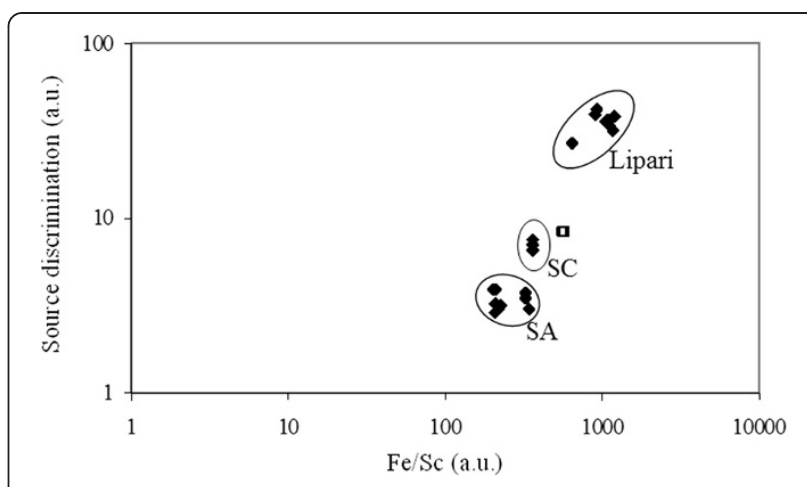

Figure 4 Multiple regression analysis: plot of the discrimination factor vs. Fe/Sc abundance ratio.

\section{Experimental}

\section{Sampling}

The sampling was directly performed on the mosaic. In Table 3 lists the characteristics of each tessera examined and the type of analysis performed.

\section{$X$-Ray Fluorescence analysis (XRF)}

We used an X-ray generator CPX-M160 Gilardoni and a planar $\mathrm{Ge}(\mathrm{HP})$ detector EG\&G Ortec having resolution $195 \mathrm{eV}$ at $5.9 \mathrm{keV}$. The distance between the tessera surface and the detector was $6.5 \mathrm{~cm}$; the measurement time of each acquisition was 180 seconds. For each tessera two different operating conditions were applied. In the first one, which allows the detection of $\mathrm{K}, \mathrm{Ca}, \mathrm{Mn}, \mathrm{Fe}$, $\mathrm{Co}$ and $\mathrm{Cu}$, the high-voltage at the filament of the X-ray

Table 3 Analyses performed on tesserae from the mosaic on the front of the San Giovenale chapel (Narni)

\begin{tabular}{|c|c|c|c|c|}
\hline & Colour & Description & XRF & ITNAA \\
\hline 1 & blue-green & transparent & * & \\
\hline 2 & blue-green & transparent & * & \\
\hline 3 & blue-green & transparent & * & \\
\hline 4 & blue-green & transparent & * & \\
\hline 5 & blue-green & transparent & * & \\
\hline 6 & light blue & translucent & * & \\
\hline 7 & light blue & translucent & * & \\
\hline 8 & light blue & translucent & * & \\
\hline 9 & light blue & translucent & * & \\
\hline 10 & light blue & translucent & * & \\
\hline 11 & dark blue & opaque & * & \\
\hline 12 & black & obsidian & * & * \\
\hline 13 & black & obsidian & * & \\
\hline 14 & black & obsidian & * & * \\
\hline 15 & white & limestone & * & \\
\hline 16 & colourless & transparent & * & \\
\hline 17 & colourless & transparent & * & \\
\hline
\end{tabular}


generator was $20 \mathrm{kV}$ and the current was $7.0 \mathrm{~mA}$. In the second operating condition, allowing the detection of $\mathrm{Pb}, \mathrm{Sr}, \mathrm{Zr}, \mathrm{Nb}, \mathrm{Sn}, \mathrm{Sb}, \mathrm{Ba}, \mathrm{La}$ and $\mathrm{Ce}$, the voltage of the $\mathrm{X}$-ray generator was $60 \mathrm{kV}$ and the power of the current of X-ray generator was $4.0 \mathrm{~mA}$, with a copper shield 0.5 $\mathrm{mm}$ thick inserted between the collimator and the X-ray tube, in order to attenuate the low energy component of the beam.

\section{Analysis of obsidian tesserae by Instrumental Neutron Activation Analysis}

Scientific methods of analysis have been used in archaeological provenance studies since long time. Over the last few decades, many diverse techniques have been applied to obsidian materials, from density measurements to Neutron Activation Analysis. We preferred to use this last technique for its analytical characteristics [3,19-30]. In fact, the methodology improvements in sample handling, precision and accuracy, along with reduced sample size requirement, made the Neutron
Activation Analysis appropriate for archaeological provenance studies [31].

In Instrumental Neutron Activation Analysis (NAA), a sample is irradiated in neutron flux from a nuclear reactor. Upon irradiation different radionuclides are produced depending upon the nature of sample, the irradiation time and the neutron flux.

Samples 12 and 14, of about $400 \mathrm{mg}$, along with blank and standards, put in nuclear-grade polyethene cylinders (Kartell, Milan, Italy), were irradiated under a neutron flux of $2.6 \times 10^{12} \mathrm{n} \mathrm{cm}^{-2} \mathrm{~s}^{-1}$ in the rotating rack of the TRIGA Mark II reactor of the ENEA-Casaccia Laboratories. The flux stability $(>99.8 \%)$ was tested irradiating $\mathrm{Au}$ standards as monitor. The high integrated flux, i.e. $1.8 \times 10^{17} \mathrm{n} \mathrm{cm}^{-2}$, allowed to investigate elements whose gamma-emitting radionuclides have half-life time ranging between 0.5 day and 15 years [19-30].

After irradiation, $\gamma$-ray spectrometry measurements of different durations were carried out using a $\mathrm{Ge}(\mathrm{HP})$ EG\&G Ortec (relative efficiency 29\%, FWHM $1.70 \mathrm{keV}$

Table 4 Nuclear data (radioisotope from $(n, y)$ reaction, cross section, half-life, peak energy) and limit of detection of the elements investigated in this study (a: calculated according to [33] and expressed as ppm; h: hour; d: day; y: year)

\begin{tabular}{|c|c|c|c|c|c|c|}
\hline Element & Product nuclide & Thermal cross section (barn) & Half life & & Y-Ray used (keV) & LOD $^{a}$ (ppm) \\
\hline As & ${ }^{76} \mathrm{As}$ & 4.3 & 26.3 & $\mathrm{~h}$ & 559.2 & 0.008 \\
\hline $\mathrm{Ba}$ & ${ }^{131} \mathrm{Ba}$ & 13.5 & 11.8 & $d$ & 496.3 & 10 \\
\hline $\mathrm{Ce}$ & ${ }^{141} \mathrm{Ce}$ & 0.57 & 32.38 & $d$ & 145.4 & 0.01 \\
\hline Co & ${ }^{60} \mathrm{Co}$ & 37.2 & 5.272 & y & 1332.5 & 0.0008 \\
\hline $\mathrm{Cr}$ & ${ }^{51} \mathrm{Cr}$ & 15.9 & 27.7 & $d$ & 320.0 & 0.09 \\
\hline Cs & ${ }^{134} \mathrm{Cs}$ & 29.0 & 2.062 & $y$ & 795.7 & 0.003 \\
\hline Eu & ${ }^{152} \mathrm{Eu}$ & 5900 & 12.7 & $y$ & 1408.8 & 0.0002 \\
\hline $\mathrm{Fe}$ & ${ }^{59} \mathrm{Fe}$ & 1.15 & 45.1 & $d$ & 1099.2 & 5 \\
\hline $\mathrm{Hf}$ & ${ }^{181} \mathrm{Hf}$ & 12.6 & 42.5 & d & 482.2 & 1 \\
\hline K & ${ }^{42} \mathrm{~K}$ & 1.46 & 12.36 & $\mathrm{H}$ & 1524.7 & 260 \\
\hline La & ${ }^{140} \mathrm{La}$ & 9.0 & 40.27 & $\mathrm{~h}$ & 1596.2 & 0.0005 \\
\hline Mo & ${ }^{99} \mathrm{Mo}$ & 0.45 & 2.76 & $d$ & 141.0 & 1 \\
\hline $\mathrm{Na}$ & ${ }^{24} \mathrm{Na}$ & 0.53 & 15.02 & h & 1368.6 & 2 \\
\hline $\mathrm{Nd}$ & ${ }^{147} \mathrm{Nd}$ & 1.3 & 11.06 & $d$ & 531.0 & 10 \\
\hline $\mathrm{Rb}$ & ${ }^{86} \mathrm{Rb}$ & 72.1 & 18.66 & $d$ & 1076.7 & 0.4 \\
\hline Sb & ${ }^{122} \mathrm{Sb}$ & 6.25 & 2.70 & d & 564.0 & 0.01 \\
\hline Sc & ${ }^{46} \mathrm{SC}$ & 26.5 & 83.85 & $d$ & 889.2 & 0.0008 \\
\hline $\mathrm{Se}$ & ${ }^{75} \mathrm{Se}$ & 51.8 & 120.4 & $d$ & 246.6 & 0.02 \\
\hline Sm & ${ }^{153} \mathrm{Sm}$ & 206 & 1948 & y & 103.1 & 0.001 \\
\hline $\mathrm{Ta}$ & ${ }^{182} \mathrm{Ta}$ & 21.0 & 115 & $d$ & 1221.3 & 0.5 \\
\hline Th & ${ }^{233} \mathrm{~Pa}$ & 7.40 & 27.4 & $d$ & 311.8 & 0.2 \\
\hline U & ${ }^{239} \mathrm{~Np}$ & 2.70 & 2.35 & $d$ & 277.6 & 0.2 \\
\hline W & ${ }^{187} \mathrm{~W}$ & 37.8 & 23.9 & h & 687.7 & 0.1 \\
\hline $\mathrm{Yb}$ & ${ }^{175} \mathrm{Yb}$ & 65 & 4.19 & d & 396.1 & 2 \\
\hline Zn & ${ }^{65} \mathrm{Zn}$ & 0.78 & 243.8 & $d$ & 1115.5 & 0.04 \\
\hline
\end{tabular}


at $1332 \mathrm{keV}$ ) connected to a multi-channel analyzer equipped with software packages (Canberra Genie 2k) for $\gamma$-spectrum analysis.

$\mathrm{Na}, \mathrm{K}, \mathrm{As}, \mathrm{Sb}, \mathrm{Br}, \mathrm{Mo}$, La, Sm, Yb, W and U, elements characterized by gamma radioisotopes with half-lives ranging between 12 hours and 3 days, were determined performing measurements of 2 hrs-long after 7 days from the end of the irradiation; a second series of measurements (24 hrs-long) were performed after about 70 days from the end of the irradiation for determining elements showing radioisotopes with long half-life time such as Sc, Cr, Fe, Co, Ni, Zn, Se, Rb, Sr, Zr, Cs, Ba, Ce, $\mathrm{Nd}, \mathrm{Eu}, \mathrm{Lu}, \mathrm{Hf}, \mathrm{Ta}$ and Th.

The analysis of reference materials is critical for all analytical techniques. Ideally, reference materials should be similar in composition to the samples of interest, since matrix effects occur for most analytical techniques. Our laboratory analyzes an in-house secondary reference material [3] to verify the instrumental drift and for quality control.

For the analysis, primary and secondary standards were used. A mixture (1 $\mathrm{mg} \mathrm{mL}^{-1}$ of each one) of primary standards (Carlo Erba, Milano, Italy) and secondary standards, such as USGS-GRX (United States Geochemical Survey) n. 1, n. 4 and n. 6, and Coal Fly Ash (NIST) n. 1633a were involved. Further, other different minerals of similar composition to the obsidian minerals were chosen as secondary materials, especially for comparing the provenience of the obsidian samples. The uncertainty of the methodology was tested measuring the secondary standards with solution of primary standards at different concentrations. All results were in agreement with the certified values except for $\mathrm{Zn}$ that is consistently lower due to the high ${ }^{46} \mathrm{Sc}$ activation interfering with the ${ }^{65} \mathrm{Zn}$ peak. In this case we used primary $\mathrm{Zn}$ standard for determining this element in the obsidian samples [17].

Table 4 reports all the nuclear data [20,32] and Limits of Detection (LODs) for the elements studied in this work.

\section{Conclusions}

The possibility to employ XRF and INAA analyses allowed to solve an important analytical problem about the characterization of the tesserae from a mosaic in Narni chapel. The obtained information was useful for determining the provenance and, particularly, the origin of the obsidians whose the tesserae are composed. The elaborations performed comparing the selected elements content between our obsidian samples and obsidian samples of well-known provenance using different statistical approach (i.e., the La/Sc vs. Cs/Sc ratio, the correlation between $\mathrm{Eu}$ and $\mathrm{Cs}$ concentrations, the source discrimination), evidenced that the obsidian samples 12 and 14 come from the deposits in Sardinia (and, presumably, they could be related to Arci Mountain site C). Considering the presence of $\mathrm{Sb}$ in the chemical elemental composition of the glass tesserae, they can be considered as reused material in such mosaic, circumstance which could suggest, similarly, a reuse also for the obsidian black tesserae.

\section{Competing interests}

The authors declare that they have no competing interests.

\section{Authors' contributions}

CS coordinated the study. CS collected the tesserae during the sampling campaign. PA and AR set up and performed the analytical procedure by means of INAA, PM performed the XRF analyses. PA, AR and CS edited the text and prepared the final draft of the paper. All the authors have read and approved the final manuscript.

\section{Acknowledgements}

This work was supported under the grant ISPESL/DIPIA/P06/L06 "Identificazione, analisi e valutazione delle conseguenze delle attività antropiche", 2009-2012.

\section{Author details}

'DIPIA, INAIL settore Ricerca, Certificazione e Verifica, via Urbana 167, 00184, Rome, Italy. ${ }^{2} U T M A T$, ENEA, via Anguillarese 301, 00123, Rome, Italy. ${ }^{3}$ UTFISST CATNUC, ENEA, via Anguillarese 301, 00123, Rome, Italy.

Received: 28 January 2013 Accepted: 7 May 2013

Published: 28 May 2013

\section{References}

1. Kilikoglou V, Bassiakos Y, Doonan RC, Stratis J: NAA and ICP analysis of obsidian from Central Europe and the Aegean: source characterisation and provenance determination. J Radioanal Nucl Chem 1997, 216:87-93.

2. Tykot RH: Determining the source of lithic artifacts and reconstructing trade in the ancient world. In Written in stone: the multiple dimensions of lithic analysis. Edited by Kardulias PN, Yerkes RW. Maryland: Lexington Books; 2003:59-85. ISBN 0739105361.

3. Seccaroni C, Volante N, Rosada A, Ambrosone L, Bufalo G, Avino P: Identification of provenance of obsidian samples analyzing elemental composition by INAA. J Radioanal NuCl Chem 2008, 278:277-282.

4. Tykot RH: Scientific methods and applications to archaeological provenance studies. In Proc Inter School Physics E Fermi. Edited by Martini M, Milazzo M, Piacentini M. Amsterdam: IOS Press; 2004:407-432.

5. Moioli P, Seccaroni C: Analysis of art objects using a portable X-Ray fluorescence spectrometer. X-Ray Spectrom 1999, 29:48-52.

6. Seccaroni C, Moioli P: Fluorescenza X. Prontuario per l'Analisi XRF Portatile Applicata a Superfici Policrome. Florence: Nardini Editore; 2002. ISBN 9788840440682

7. Visco G, Ridolfi S, Plattner SH, Gigante GE: Razors, horse bits or axes; search of the different composition in common use bronze Villanovan objects (VIII-VII century B.C., Italy) by multivariate analysis. Curr Anal Chem 2010, 6:11-18.

8. Hallam BR, Warren SE, Renfrew C: Obsidian in Eastern Mediterranean: Characterisation by Neutron Activation Analysis and Optical Emission Spectroscopy. Proc Prehistoric Soc 1976, 42:85-110.

9. Ammerman AJ, Cesana A, Polglase C, Terrani M: Neutron Activation Analysis of Obsidian from Two Neolithic Sites in Italy. J Arc Sci 1990, 17:209-220.

10. Bigazzi G, Meloni S, Oddone M, Radi G: Provenance studies of obsidian artefacts: trace element analysis and data reduction. J Radioanal NuCl Chem 1986, 98:353-363.

11. Tykot RH: Characterization of the Monte Arci (Sardinia) obsidian sources. J Archaeo Sci 1997, 24:467-479.

12. Oddone M, Bigazzi G: Studi di provenienza delle ossidiane del bacino del Mediterraneo: caratterizzazione delle fonti naturali di materia. J Intercul Interdisciplinary Archaeo/ 2004, 3:1. available at http://v01.jiia.it/J||A.it/ 
Sezione_II/IIA_01/Oddone-Bigazzi_F01/Articolo_F01/Oddone-Bigazzi_pag1. html.

13. Bigazzi G, Oddone M, Radi G: The Italian obsidian sources. Archeo Múhely 2005, 1:1-13. available at http://www.ace.hu/am/2005_1/AM-2005-1-GB.pdf.

14. Aspinall A, Feather SW, Renfrew C: Neutron activation analysis of Aegean obsidians. Nature 1972, 237:333-334.

15. Ammerman AJ, Cesana A, Polglase C, Terrani M: Neutron Activation Analysis of obsidian from two neolithic sites in Italy. J Archaeo Sci 1990, 17:209-220.

16. Tykot RH: New approaches to the characterization of obsidian from the Mediterranean island sources: interpreting chronological change in neolithic Sardinia and Corsica. Mat Res Soc Symp Proc 2002, 712:6-||4. 1-\|4.6.15.

17. Mommsem H, Sjöberg BL: The importance of the 'best relative fit factor' when evaluating elemental concentration data of pottery demonstrated with Mycenaean sherds from Sinda, Cyprus. Archaeometry 2007, 49:359-371.

18. Sayre EV: The intentional use of antimony and manganese in ancient glasses. In Advances in Glass Technology, Part 2: Historical Papers and Discussions. Edited by Matson FR, Rindone GE. New York: Plenum Press; 263:282. ISBN 1258400243.

19. Campanella L, Crescentini G, Avino P, Moauro A: Determination of macrominerals and trace elements in the alga Spirulina platensis. Analusis 1998, 26:210-214.

20. Djingova R, Kuleff I: Instrumental techniques for trace analysis. In Trace Elements - Their Distribution and Effects in the Environment. Edited by Markert B, Friese K. Amsterdam, The Netherlands: Elsevier; 2000:137-185. ISBN 0-444-50532-6.

21. Avino P, Carconi PL, Lepore L, Moauro A: Nutritional and environmental properties of algal products used in healthy diet by INAA and ICP-AES. J Radioanal Nucl Chem 2000, 244:247-252.

22. Avino P, Capannesi G, Rosada A: Characterization and distribution of mineral content in fine and coarse airborne particle fractions by Neutron Activation Analysis. Toxicol Environ Chem 2006, 88:633-647.

23. Avino P, Capannesi G, Rosada A: Heavy metal determination in atmospheric particulate matter by Instrumental Neutron Activation Analysis. Microchem J 2008, 88:97-106.

24. Capannesi G, Diaco L, Rosada A, Avino P: Investigation of trace and ultratrace elements of nutritional and toxicological significance in Italian potable waters by INAA. J Radioanal Nucl Chem 2008, 278:353-357.

25. Capannesi G, Rosada A, Avino P: Elemental characterization of impurities at trace and ultra-trace levels in metallurgical lead samples by INAA. Microchem. J 2009, 93:188-194.

26. Avino P, Capannesi G, Diaco L, Rosada A: Multivariate analysis applied to trace and ultra-trace elements in Italian potable waters determined by INAA. Curr Anal Chem 2010, 6:26-36.

27. Capannesi G, Rosada A, Avino P: Radiochemical separation and anticompton analysis of $\mathrm{Ni}, \mathrm{Sn}, \mathrm{Te}$ and $\mathrm{Zn}$ in lead standard reference materials at ultra-trace levels. Curr Anal Chem 2010, 6:217-222.

28. Avino P, Capannesi G, Manigrasso M, Sabbioni E, Rosada A: Element assessment in whole blood, serum and urine of three italian healthy sub-populations by INAA. Microchem J 2011, 99:548-555.

29. Capannesi G, Rosada A, Manigrasso M, Avino P: Rare earth elements, thorium and uranium in ores of the North-Latium (Italy). J Radioanal Nucl Chem 2011, 291:163-168.

30. Avino P, Capannesi G, Renzi L, Rosada A: Instrumental neutron activation analysis and statistical approach for determining baseline values of essential and toxic elements in hairs of high school students. Ecotoxicol Environ Saf 2013, 92:206-214.

31. Djingova R, Arpadjan S, Kuleff I: INAA and flame AAS of various vegetable reference materials. Fresenius J Anal Chem 1991, 339:181-186.

32. Leclerc JC, Cornu A, Ginier-Gillet A: Neutron Activation Analysis Tables. London: Heyden; 1989. ISBN 0-471-25846-6.

33. Currie LA: Limits for qualitative detection and quantitative determination. Application to radiochemistry. Anal Chem 1968, 40:586-593.

doi:10.1186/2050-7445-1-17

Cite this article as: Avino et al: Obsidian use in the mosaic of the St. Juvenal church, Narni (Italy): chemical characterization and origin. Heritage Science 2013 1:17.

Publish with ChemistryCentral and every
scientist can read your work free of charge
"Open access provides opportunities to our
colleagues in other parts of the globe, by allowing
anyone to view the content free of charge."
W. Jeffery Hurst, The Hershey Company.
- available free of charge to the entire scientific community
- peer reviewed and published immediately upon acceptance
- cited in PubMed and archived on PubMed Central
- yours - you keep the copyright
submit your manuscript here:
http://www.chemistrycentral.com/manuscript/

